\title{
The Overshadowing Presence of Toxic Masculinity and a Call for Reducing Sexism in Khaled Hosseini's A Thousand Splendid Suns
}

\author{
Md. Shahjahan Kabir \\ English Discipline, Khulna University, Khulna-9208, Bangladesh
}

KUS: 21/22:051121

Manuscript submitted: 5 November, 2021

Accepted: 3 January, 2022

\begin{abstract}
The nexus among toxic masculinity, sexism, and patriarchy; and women's oppression as an upshot of these have been potential issues stirring the interest of the researchers for centuries. The researches done on Khaled Hosseini's A Thousand Splendid Suns are not exceptional than those works. As the novel blatantly exposes the plight of womenfolk amid an excessive masculine setting, Hosseini's covert signal towards the male characters' poignant situation due to their toxic masculinity has been an unaddressed issue. This article aims at studying the detrimental consequences of toxic masculinity in the characters' personal, familial, and social life showing the utter helplessness of male characters who have to comply with the stereotyped notion of gender roles of real men. Because of the male characters' vague notion of masculinity, the relationship with their partners becomes toxic; Jalil does not get forgiveness from his daughter Mariam when he asks for and Rasheed's life ends horribly. Demonstrating the poignant aftermaths of toxicity, the researcher calls for reducing sexism for establishing a healthy relationship where partners will have love, respect, and trust between or among themselves.
\end{abstract}

Keywords: Chauvinism, helplessness, hypermasculine, oppression, sexism, toxic masculinity

\section{Introduction}

Khaled Hosseini in his second novel A Thousand Splendid Suns (2007) voices the story of devastations, exploitations, and sorrows of Afghan people, especially Afghan women whose lives are controlled by patriarchy. In conjunction with the boundless miseries of women, this novel reconnoiters the impalpable pains of men's life. Hosseini rationally sheds light on the secret world where men suffer, tolerate, and scuffle into desolations. Through his classic story, Hosseini attempts to convey the destructive effects of toxic masculinity in men's life. His two major male characters: Jalil and Rasheed never get any compassion from the characters in the novel as well as from the reader even when they suffer, because they have been fierce to women. Their tragedy lies here. Their quasi notion of masculinity carcasses their self, encumbers their thinking power, and militaries them to deny their weakness. This incapability to express innermost agony internally plagues them with enormous mental pains. They become captive in their peculiar rules and cannot escape the trap of chauvinism. The objectives of this paper are to explore the chauvinist attitude of the male characters towards female, simultaneously to investigate their silent victimization and pains in the novel. By 
focusing on the harmful effects of toxic masculinity on both female and male characters, this study calls for a hale and hearty world where no sexism will be subsisted.

\section{Theoretical Framework}

In the present culture, the word toxic means a group of attributes that negatively affect a person or people's belief, behaviour, and activities; and masculinity refers to "a set of practices, norms, and behaviours associated with the idea of being male, believed to stand in opposition to femininity and women" (Waling, 2019, p. 2). In academia, toxic masculinity is considered orthodox, dogmatic, hegemonic, unhealthy, etc. It indicates 'toxic practices' of masculinity bolstering oppression, violence, and exploitation of women and trans-genders (Connell, Messerschmitt \& de Boise as cited in Waling, 2019, pp. 4-5). Toxic masculinity upholds the issues that make men like machines-it depersonalizes them and makes them stigmatized. Chaplin and Aldao in "Gender differences in Emotion in Children: A Metaanalytic Review" (2013) express that; adolescent boys express less anger than adolescent girls. But as the boys grow up, they have to shoulder the attributes expected by society and culture which are usually patriarchal. It deteriorates men's mental health and causes hopelessness, anxiety, lack of confidence, etc. Brown in 2017 tells that, relationships between or among partners become toxic when they "engage in a set of psychological, sexual, financial, and/or physical practices of abuse that can lead to a number of negative and harmful outcomes to someone experiencing the toxicity" (as cited in Waling, 2019, p. 4). Toxic masculinity refers to the belief that manliness prolongs domination and aggression. It upholds toxicity. E.H. Thompson and J.H. Pleck in "The Structure of Male Norms" (1986) identify three core components of toxicity:

1. Toughness: The belief that men are strong and aggressive in behaviour and emotionally uncaring.

2. Antifemininity: Men do not possess emotions that are considered feminine like being weak, sympathetic, emotional, etc.

3. Power: It is the belief that if men can obtain power, they can earn status.

A study done in 2019 found that men who endorse toxic masculinity do not assist or console a victim (Ingram et al.). The pressures of toxic masculinity met by men have drastic consequences. There are not many rudimentary differences in the behaviour between young boys and girls. But toxic masculinity shapes men's behavior and makes them believe that a real man does not have any sensitivity. Thus, throughout their life men have to shelter the myths of patriarchy which force them to hide their authentic self and inward sentiment.

In A Thousand Splendid Suns, Khaled Hosseini reveals the persecuted condition of men whose anguishes are always unobserved by the social order as well as academic researches. Through his representation of Jalil and Rasheed, Hosseini reveals the veiled truth of men's lives and their silent sorrows. Their belief in toxic masculinity and offensive behaviour alienate them from their loved ones. They cannot express their feelings because of the stereotyped rules of the society. This paper will problematize these issues and try to provide a message for reducing sexism.

\section{Literature Review}

A good number of researches have been done on A Thousand Splendid Suns. In "A Legitimate End to Illegitimate Beginning: A Critical Analysis of Mariam's Character in A Thousand Splendid Suns" (2017), Akhtar et al. discuss the struggle of Mariam who tries to attain her distinctiveness fighting against the identity that society has bestowed upon her. Through close textual analysis, the researchers dig deep into the journey of Mariam from an illegitimate child to a legitimate one. The study tells that this novel is one of the finest 
examples of women's subjugation and oppression in a typical Taliban setting. The text shows the horrible truth of a society that makes a child illegitimate if the father refuses to provide legitimacy. Mariam is fated to be born as a harami and leads a life devoid of self-respect. The deprivation haunts her so much that she decides to resist. Her resistance shows that she cannot tolerate it anymore. Though she faces the death penalty, her resistance makes her a vigorous feminist. Her death symbolizes "the most credible decision to get away from the precarious assault of the Soviet Union, the tyrannical regime of the Taliban, or an offensive husband" (Akhtar et al., 2017, p. 116).

In "Feminine Power as Represented in Khaled Hosseini's The Thousand Splendid Suns" (2016), Aneeta Sebastian discusses how Afghanistan has been a horrible place for women centuries after centuries. In Afghanistan, women have been subjugated thrice: "socially, politically and culturally" (Sebastian, 2016, p. 52). In the beginning, the researcher introduces the author of the novel. She admires the author because in the case of Hosseini, gender does not work as a hindrance to describe the plight of another gender. He skillfully narrates the touching story of womanhood. While talking about the cruelty of patriarchy expressed through illegitimacy, deprivation, discrimination, child marriage, violence, etc. in the novel, Sebastian refers to the report about women released by The United Nations Statistics Division (2016):

- Afghanistan is one of the most challenging places in the world to be a woman.

- Many women die in pregnancy and childbirth: 460 deaths/100,000 live births (2010)

- $85 \%$ of women have no formal education and are illiterate. (as cited in Sebastian, 2016, p. 52)

According to Sebastian, as the novel's setting is Afghanistan, Hosseini portrays the real scenario of the country. Patriarchy decides the fate of the women folk-what they will do, eat, wear, or whom to marry. Sebastian reads the novel from a feministic point of view and she claims that the author advocates for reducing gender violence.

Stefani Amanda Anggi Riany in "The Impact of Oppression toward Women Seen through Two Women Characters in Khaled Hosseini's A Thousand Splendid Suns" in 2016 analyses Mariam and Laila's poignant sufferings and how the miseries impact their attitude and behaviour. The researcher studies the oppression faced by Mariam and Laila using five faces of oppression: exploitation, marginalization, powerlessness, cultural imperialism, and violence theorized by Iris Young in 1992. Riany has found that in both Mariam and Laila's cases, oppression leads them to resistance.

Azam Kazemiyan in "A Thousand Splendid Suns: A Rhetorical Vision of Afghan Women" (2012) tells that, though Afghan women vividly came to the notice of the world as the victims of war and violence after the occurrences on the world trade center, very few popular narrative fictions represented the difficulties of Afghan women. Kazemiyan like many scholars believes that western media misrepresented Afghan women and their struggle. As media is a strong source of information for those who do not have firsthand experience of Afghan women, U.S. media intentionally presented women as passive, oppressed, victimized to legitimize grounds for U.S. involvement and imperialist domination in Afghanistan. The researcher studies the situation of women in urban and rural settings and finds that in rural areas women contributed much in economy. In the city areas, girls were educated, wore burqas according to their wishes. From 1919 to 1929, the reforms made by King Amanullah advanced the condition of women. In 1953, when Daoud Khan came to power, women actively took part in government and the workforce. In 1978 Soviet Union took hold of power and women's development was the chief priority then. But during the Mujahidin and later in the Taliban rule, there were many restrictions on women. The researcher intensively studies the available resources and finds that Afghan women were not only passive sufferers of the 
war or the state; they were also makers of societal revolution. Kazemiyan argues that Khaled Hosseini's depiction of Afghan women goes in line with U.S. media that presented Afghan women as subjugated to legitimize U.S bombing in Afghanistan. The novel is not an innocent attempt to improve the situation of women. The author supports imperialism through his projection of women as helpless.

G. Iynisha \& Dr. K. Shanthi in "Masculinity: A Gamut in A Thousand Splendid Suns" (2018) study A Thousand Splendid Suns from the perspective of the fluidity of masculinity telling the boundary of manliness is not fixed, for the characters often go beyond the expected norms of gender. They discuss varied perspectives of masculinity and find masculine traits in the female characters. They explain that the author presents caring masculinity along with hyper masculinity. Hakim, Zaman, and Tariq are representatives of caring masculinity. Jalil and Rasheed symbolize hyper masculinity who think their pride is associated with domination and violence. Nana blurs stereotyped gender roles by giving birth to Mariam alone, showing anger and mistrust of Jalil openly. Mariam and Laila also expose masculine vigor in their resistance.

Yeasmin in "Khaled Hosseini's A Thousand Splendid Suns: A Saga of Afghanistan" (2020) links Afghan history and the history presented in the novel using New historic approach. She says that the novel recounts three decades of Afghan social, economic, cultural, and political history. She studies the historical documents about Daoud Khan's regime, the time of the Soviet Union, the Mujahedeen, and the Taliban rule; and analyses the textuality of history in the novel. She finds that Afghanistan had a rich cultural heritage but "The cultural landscape of Afghanistan underwent a radical change because of the nasty play played in the name of religion" (Yeasmin, 2020, p. 383). Hosseini also presents religion as the key determiner of controlling the fate of the people in Afghanistan bolstering "upheavals, destruction, violation, war, exploitation and loss" (Yeasmin, 2020, p. 383). The author recreates political upheavals, child marriage, gender discrimination, the resistance of women through the story of Mariam and Laila. The researcher concludes that Hosseini authentically draws the picture of worn-torn Afghanistan and hence the novel turns into a saga of Afghanistan.

Yeasmin \& Islam study a different issue in "The Concept of Parenthood in Khaled Hosseini's The Kite Runner and A Thousand Splendid Suns" (2021). They explain the protagonists' plight that culminates in their sense of parenthood. In the novels, they find the supremacies of human relationships-father-son, and mother-daughter-that do not always need blood connection. Hosseini in the novels provides a new outlook to comprehend human bonding that is based on love, trust, and responsibility. In Amir and Mariam's cases, their sense of hollowness, deprivation of love, and craving to attain a status for curing their bloody souls lead them to involve in the journey to rescue Sohrab and Laila; and in this way, they get the ultimate bliss in their lives; they become parents to Sohrab and Laila.

In A Thousand Splendid Suns, exploitation of patriarchy, female subjugation, identity formation, war, loss and imperialism are the issues that have been researched by the researchers. No research has been done on the concept of toxic masculinity and its severe impacts on men's psyche. The victimization of men to meet up the norms of male chauvinism has been an ignored issue. No research urges for reducing sexism. This article will try to address these issues and fill up the gaps.

\section{Methodology}

This study is qualitative research. So, the researcher has followed content analysis method to write this paper. It is concerned with the victimized condition of men whose sufferings are often unnoticed by the society. It aims at analysing how toxic masculinity intoxicates men's 
psyche and makes them violent, unemotional and sexually aggressive. This study is based on two types of sources of data: Primary source and secondary sources of data are used to write this paper. The text of Khaled Hosseini's A Thousand Splendid Suns is used as the primary source of data and related journals, articles, books, criticisms and web pages are used as the secondary sources of data.

\section{Discussion}

The discussion on A Thousand Splendid Suns is divided into three parts. In the first part, the consequences of Jalil and Rasheed's toxic masculinity on the lives of women are described. In the second phase, the pitiable situation of Jalil and Rasheed as the victims of their toxic masculine values is explained. And in the third phase, the researcher eagerly appeals for the reduction of sexism to create a healthy relationship which is crucial for establishing a healthy world.

\section{Toxic masculinity in Jalil and Rasheed}

A Thousand Splendid Suns narrates a story of a male chauvinist world where men practice their strength to show their sovereignty over women. This toxic notion of masculinity makes them dispassionate, vicious, and sexually antagonistic. Jalil and Rasheed are also driven by this malevolent force and outline their lives to be real men, to be "the true agents of sexism" (Sebastian, 2016, p. 53). Both characters practice radical patriarchy that does not show respect towards women.

\section{Jalil and Rasheed as Selfish, Sexually Aggressive and Tyrant Husbands}

In the opening part of the novel, Hosseini gives a glimpse of a patriarchal society that privileges the male folk to enjoy supreme authority to exploit women psychologically and physically. The novel shows the horrible truth of a society that makes a child bastard if the father does not acknowledge it. The situation is so worse that in "an Afghan patriarchal setup, men enjoy complete authority over women, whether it is their wife or a stranger on the street, a woman must comply with every order put to her" (Akhtar et al., 2017, p. 113). Two major male characters in this novel play the roles of tyrants who satisfy their desires by oppressing and torturing women. Jalil who is the father of Mariam (the protagonist) enjoys affluent status without any anxiety for defame for what he has done with Nana and then with Mariam. Jalil shows his selfishness towards Nana. When Nana is working as a servant at Jalil's house, Jalil builds up an illegal relationship with her. As a member of a powerful class, Jalil takes that opportunity and impregnates Nana. Despite legitimating their relations, he abandons Nana. After that, Jalil arranges a living place for her (a tiny kolbaat the outskirts of the city Herat). There he leaves Nana to grieve the pangs of woes alone. Even during the delivery of Mariam, Jalil does not come to impart her with mental support.

Jalil hadn't bothered to summon a doctor, or even a midwife, even though he knew that the jinn might enter her body and cause her to have one of her fits in the act of delivering. She lay all alone on the kolba's floor, a knife by her side, sweat drenching her body (Hosseini, 2007, p. 11).

Jalil's selfishness makes Nana's life miserable and later forces her to commit suicide. Jalil never tries to understand the emotion of Nana because a real man does not show sympathy towards anyone, especially women. The idea of masculinity makes him believe that a man can do anything with a woman.

In Mariam's case, as Jalil refuses to legitimize the relation, her pangs begin the day when her mother conceives her. She becomes a matter of shame to the mother even before her birth and realizes the meaning of harami-“an ugly, loathsome thing to be a harami, like 
an insect, like the scurrying cockroaches" (Hosseini, 2007, p. 4) in her childhood. She understands that "a harami was an unwanted thing; that she, Mariam, was an illegitimate person who would never have a legitimate claim to the things other people had, things such as love, family, home, acceptance" (Hosseini, 2007, p. 4). For this reason, after her mother's suicide, she cannot stay at her father's palace even for a week and enjoy the facilities like Jalil's legitimate children. She is obliged to marry Rasheed, a man of forty-five at the age of fifteen as Jalil has decided. She craves for her father's acceptance but fails. But being a woman, she yields to patriarchy.

Rasheed is a more violent and sexually aggressive character who constantly tortures his wives. Rasheed humiliates Mariam disguising him as a protecting husband. Mariam tries to cope up with the disdain, ferocity, ridicule, and rage of her husband. She turns into an outsider when she disappoints the husband not being able to give birth to a male child. In Afghan society, bearing a male child is the criterion for dignity and respect; son "means 'immortality' because he is the source to carry on the family name and the role of women in the patriarchy" (Akhter et al., 2017, p. 114). As Mariam misses the mark, she lacks respect. Rasheed's terror dehumanizes her; she endures violence like the archetypal characters in Afghanistan, "Mariam's life is the example of the situation of other women in Afghanistan who are leading a life in constant fear of their husbands" (Akhter et al., 2017, p. 115). Rasheed's sense of toxic masculinity offers a route to exercise power and control over powerless Mariam.

Rasheed's false consciousness of masculinity turns him into a caricature of chauvinism. Rasheed's relationship with Laila also echoes the unequal power relations within the patriarchal social structure. Laia's traumatized experience universalizes the concept that "women's suffering cannot be interpreted from a single perspective" (Azzi and Belkhiri, 2019, p. 23). Unlike Mariam, she is educated and progressive. However, she is also a subject to Rasheed. Though her situation in the domestic world is not as tumultuous as Mariam, she becomes a victim when she gives birth to Aziza to whom Rasheed never shows affection. Her subjugation deteriorates when she along with Aziza and Mariam are caught for escape. Rasheed locks Laila and Aziza in a room without food, water after beating Laila and Mariam. Even, he wants Aziza to be a beggar when he has a financial crisis. Laila gets ill-treatment, often violent beating when she counters Rasheed for saving Aziza from his inhumanity. His aggression and assault entwine in toxic masculine myth. Henceforth, when Zalmai tells Rasheed about Tariq's several visits to his home, his masculine pride gets so insulted that he decides to kill his wives:

Mariam lost count of how many times the belt cracked, how many pleading words she cried out to Rasheed, how many times she circled around the incoherent tangle of teeth and fists and belt ... He let go of Laila and turned on her .. . He was still on top of Laila, his eyes wide and crazy, his hands wrapped around her neck. Laila's face was turning blue now, and her eyes had rolled back. Mariam saw that she was no longer struggling. He's going to kill her, she thought. He really means to. (Hosseini, 2007, pp. 338-40)

Both characters become so gripped by their masculine conceit that they consider women as objects who are born to satisfy men's wishes and to give birth to male children. Toxic masculinity administers their soul and influences them to become more vicious, cold, and antagonistic.

\section{Jalil and Rasheed as Dictators of Women's lives}

The socially constructed rule of patriarchy allows men to lead their lives according to their wishes, "Women always exist as the others under the clutches of this evil system and belief 
them worthless" (Yeasmin, 2020, p. 385). As a patriarchal state, sadistic air governs outside and home in Afghanistan, "women have been complying with the norms given by patriarchy generations after generations and so, are oppressed and marginalized" (Yeasmin, 2020, p. 385). In A Thousand Splendid Suns, both Jalil and Rasheed play the role of dictators in women's lives; and Nana, Mariam, and Laila are the worst sufferers of their violence. Jalil has three legal wives who are controlled by his command. His wives cannot speak against him despite knowing their husband's illegal affair with Nana, their maidservant.

As the sole power of legitimizing a relation is in the hand of the man concerned and no distinct government law exists, it is another oppressing tool to harass women. Nana and Mariam realize how "Illegitimacy acquires a grave meaning in a highly patriarchal society" (Sebastian, 2016, p. 52). Mariam's identity as an illegitimate child defines her fate even before her birth and this identity remains instrumental in her life afterward: her life in little kolba, her craving for Jalil and her abandonment of Nana, Nana's suicide, her marriage with Rasheed and his ill-treatment, her endeavor to confront Rasheed and all other things.

Like Jalil, Rasheed is also obsessed with the thought of male supremacy. Henceforth, he feels the real man's burden to govern the life of women as weaker creations. After marriage, Mariam is allocated to a guest room in Rasheed's house, she acts like a wife, she cooks food, cleans house, wears a burqa and does everything to please Rasheed. She feels herself prized until Rasheed feels her worthy to give birth to a male child. After several miscarriages, Rasheed does not feel any gut to care for her. Nothing can please Rasheed. The fear of Rasheed's menacing fury obliterates her expectation of a good future and haunts her day and night. In Afghanistan, women are only reproductive machines-sexual objects. When Mariam fails to prove her fertility, Rasheed turns to Laila and understatements Mariam now and then for this. She comprehends that women are silent subjects living in the margin. Her comprehension echoes John Berger's note "In a patriarchal society, women are split subjects who watch themselves being watched by men. They term themselves into objects because femininity itself is defined by being gazed upon by men" (qtd. in Azzi \& Belkhiri, 2019, p. $31)$.

The political and societal disorders inexorably worsened the women's status. Moghadam assures, "the issue of women's rights in Afghanistan has been historically constrained by the patriarchal nature of gender and social relations deeply embedded in traditional communities" (as cited in Ghosh, 2003, p. 3). Each régime put margins for women. It perpetuated patriarchal terrorism at home and outside. In 1995 Johnson defined patriarchal terrorism as "the terrorist control of wives by husband that involves the systemic use of not only any violence but also financial subordination, threats, isolation, and other control tactics" (as cited in Kazemiyan, 2012, p. 63). During the Mujahedeen and Taliban rule, women were extensively subjected to rape, torture, forced marriage, killing which were parallel to the overriding male dominance at home. In the novel, Laila and Mariam fail to escape the suffocating domestic world as they are caught red-handed by the police and are bound to come back home. As the state is in favour of the males, Rasheed tortures them more after their failed attempt to escape. The Taliban claimed to establish an Islamic state implementing Sharia law but paradoxically their actions told something contrary:

The message was also written in flayers, tossed into the streets. Mariam found one in the yard ...

Attention women:

You will stay inside your home at all times. . . If you go outside, you must be accompanied by a mahram, a male relative. .

You will not under any circumstances, show your face. You will cover with burqa outside. If you do not, you will be severely beaten . . . 
Girls are forbidden from attending school. All schools for girls will be closed immediately.

Women are forbidden from working. (Hosseini, 2007, p. 271)

Islam has given esteem and right to women but the rulers in Afghanistan repressed women putting on the mask of religion. Jalil and Rasheed are privileged to execute their power on women like other males of the state since the law offers hegemony.

\section{Consequences of Toxic masculinity on Jalil and Rasheed's lives}

In A Thousand Splendid Suns Khaled Hosseini also impliedly points to the victimized condition of men (trapped in the dungeon of masculinity) whose sufferings are most often unnoticed by society. Jalil and Rasheed dare not to express their feelings because of their fear of falling down from the standards of the chauvinist society.

\section{Inability to Express Emotions}

Toxic masculinity emphasizes that men must be harsh and impassive. If anyone fails to comply, he will be tagged as weak as a woman. This myth of gender roles enforces men to be confined within their world. In A Thousand Splendid Suns, Jalil and Rasheed face such kind of dilemma in their perspective lives. Because of the fear of masculine norms, they constantly fail to express their feeling towards their loved ones. Jalil, a selfish husband, and unfaithful father does not tell Nana and Mariam about his affection towards them. Society forbids him to accept his servant mistress as his wife. In the case of Mariam, Jalil could be an ideal father, but he is not brave enough to face social criticism. Therefore, the time when Jalil realizes Mariam's irresistible thirst for him, for legitimization, he hides his helplessness by avoiding her. He does not meet Mariam as promised and shows the highest level of insincerity when Mariam comes to meet him on her fifteenth birthday at his house. He dares not to encroach upon the strictures of society by providing Mariam with inheritance. However, he does what he can do at best; he sends food for Mariam, warms her with a blanket, orders the driver to take back her safely. He observes her from the upstairs window but is unable to come closer, "The face was there for only an instant, a flash, but long enough" (Hosseini, 2007, p. 34). He knows that he needs to wake Mariam from her dream world where Jalil is the king-loving, caring, and sincere father and Mariam is his precious princess. Since he cannot offer her what she expects, he must shake her make-belief world and put her in reality. One may argue, Jalil is the master of the house and so if he wanted to legalize his relation with Nana and Mariam, his wives would not raise their voices. But the reality is, he fears losing his status and fame by accepting a maid as his wife and Mariam as his child. Hence, during the marriage of Mariam, Jalil does not express his love to her. He cannot answer Mariam's blame. His powerlessness is evident in his behavior:

Jalil looked down, and, like an overgrown child, dug at something with the toe of his shoes.

"You were ashamed of me."

"I'll visit you," he muttered. "I'll come to Kabul and see you. We'll-"'

"No. No," she said. "Don't come. I won't see you. Don't you come ...

He gave her a wounded look. (Hosseini, 2007, p. 55)

Jalil's incapability to express his love and affection shows the level of his helplessness. No one can understand the inner agony that hurts him. His heart is broken into pieces, he feels the pains of loss but due to his masculine mask he can't cry, he can't scream, he can't tell that his heart is flouting:

She (Mariam) could hear him (Jalil) following her. When she reached the hydraulic doors, she heard him behind her. 


\begin{abstract}
"Mariam jo."
...

She did not turn to look when Jalil's palms pressed on the glass, when his knuckles rapped and rapped on it. When the bus jerked forward, she did not turn to see him trotting alongside it. And when the bus pulled away, she did not look back to see him receding, to see him disappear in the cloud of exhaust and dust. (Hosseini, 2007, p. 55)
\end{abstract}

Likewise, Rasheed also fails to express his anguish and passion. Whenever he faces woe, gets hurt, feels passion, he suffers silently because the man-made law does not permit him to show any feeling except to his male child. Rasheed does not express his emotion to Mariam because if it happened Mariam could think him a weak man. In the novel, Rasheed lost his first wife and son. This loss creates a sense of emptiness in his mind. He marries twice and after marriage, he takes Mariam to show her Kabul city, restaurant, throws a party when he knows Mariam's pregnancy. Mariam gets the honor and care that she desired. But after several miscarriages, his expectation for having a male child is lost, he becomes morose and finds fault in everything. In Afghanistan, "fertility and motherhood are considered as shields, a resistance mechanism" (Azzi \& Belkhiri, 2019, p. 44) to attain value in domestic space. This chauvinistic notion about fertility leads to sexual assault and domestic violence. In Rasheed's case, he turns into a dominant, vicious, and hostile husband like other typical husbands in the country.

Rasheed's sense of masculinity teaches him to be uncompromising in any situation. He is adamant to retain his masculine pride by all means. Rasheed remarries to have a son. Though he takes advantage of Laila's helplessness, it is unavoidable that he saves Laila from further adversities. He tells Mariam the cause of his decision to marry Laila, "But I suspect she won't get far. No food, no water, not a rupiah in her pockets, bullets and rockets flying everywhere. How many days do you suppose she'll last before she's abducted, raped, or tossed into some roadside ditch with her throat slit?" (Hosseini, 2007, p. 209). Even though Rasheed has the hidden agenda to have a son through Laila, one thing should be acknowledged that he provides Laila, "A home and a husband" (Hosseini, 2007, p. 209) or else Aziza would be regarded as a harami from her childhood. Marrying Laila, he tolerates a lot; he tolerates Aziza who is not his child. He hears rumors about Laila and Tariq's affair. After Aziza's birth, he gets more suspicious and becomes sure through Laila's several activities. Aziza is a female child, and he doubts the identity of Aziza. Hence, he is not eventempered to Aziza. He gets totally unbending knowing Laila's extramarital relationship. It hurts his masculine pride and proves him weak to society. Something is happening behind him that defiles his house and raises questions in his son's innocent mind. It is unpardonable to him. He realizes that Laila just marries him to provide a secure fate for her child, Aziza. She has never been loyal and devoted to him. As chauvinistic laws teach him to exert control on women, he is unwilling to compromise and decides to end their lives who insult his masculinity.

Being a man, he suffers silently. He is not able to share his aches with anyone: he has lost his first wife and son, witnessed many miscarriages of his second wife, and remains childless for many years, his third wife is not loyal, he is rearing a bastard child in his home. He suppresses his inner pain and behaves like a strong man to show that man has no need and is not bothered by woe.

\title{
Patriarchy and Toxic Masculinity
}

Toxic masculinity forces men to shape their life according to the laws of patriarchy. When men use the patriarchal rule to dominate women, ironically, they themselves also fall into 
their own traps. Like women, they also become the victims of toxic masculinity. Jalil and Rasheed suffer silently, they can't show their feelings. Toxic masculinity intoxicates their inner self, snatches, and makes them masculine puppets who can only perform the roles of strong men. Jalil and Rasheed's unseen pains and sufferings silently drive them to their psychological destructions.

Jalil's letter to Mariam which is read by Laila after his and Mariam's death shows how much Jalil loved Mariam. Though he had not legalized Mariam when she craved for him, he repented a lot afterward. He went to Mariam to seek forgiveness, but he failed. In his letter he expressed his fatherly affection for her, "I miss you. I miss the sound of your voice, your laughter. I miss reading to you, and all those times we fished together. . You were a good daughter Mariam jo, and I cannot ever think of you without feeling shame and regret" (Hosseini, 2007, p. 393). He apologized for his inability to welcome Mariam into his home. He understood the reason why he was a coward then; he did that behaviour for the "Fear of losing face? Of staining my (his) so-called good name?" (Hosseini, 2007, p. 394). Now, after experiencing many touches of melancholy he understood the futility of all his pride-the pseudo notion of masculinity, "Perhaps this is just punishment for those who have been heartless, to understand only when nothing can be undone" (Hosseini, 2007, p. 394). Because of his toxic chauvinism, he died with the ache of an undeserving father.

Rasheed's life also ends horribly for his toxic masculinity. As "Human behaviour is determined by society and environment" (Riany, 2017, p. 1), his behaviour is also affected by patriarchal rules and regulations. He is born and brought up a in strictly patriarchal setting where males are always supreme, and women are their subjects living in the periphery. Males are masters at home and outside. These norms legalize bullying and aggression. Rasheed is also violent to his wives. However, he is not a solely brutal man devoid of the warmness of his heart. He is never miserly to show his love and care for his son, Zalmai. He buys toys, clothes, diapers, gargets often beyond his reach. He takes Zalmai to his shop, if he does any mistake; he scolds him softly and calmly. They come back in the evening, even at that time he is not tired. Zalmai bounces him, he sits beside him. They play private games, "His patience with Zalmai was a well that ran deep and never dried" (Hosseini, 2007, p. 289). Until Mariam's proven infertility, he is not so ill-tempered. In the case of Laila, until she attempts to escape Rasheed is not violent in his behaviour with her. Sometimes he criticizes her for not caring for him after the birth of Aziza and he does not show affection for Aziza. But Laila is an escapist from the beginning of her marriage. When Laila dupes Rasheed by giving the news that she is conceiving his child, Rasheed says prayers, cares for her in every means but he does not get the return, "Rasheed, anxious and overtly attentive, was holding her elbow, directing her across the yard like a traffic policeman." (Hosseini, 2007, p. 229). Sometimes he mentions, "You're safe with me, my flower, my gul. No one tries to harm you; I'll rip out their liver and make them eat it." (Hosseini, 2007, p. 224). However, when he becomes aware of his wife's extramarital relationship and another wife's support in this matter, his sense of toxic masculinity moves him to take the vehement decision ever-he decides to kill his wives. He dies at the hand of his wife, Mariam, who resists all the cruelties he has done on her to exert his masculinity.

\section{A Call for Reducing Sexism}

In a social milieu, normally, males and females are in binary oppositions and the gender roles are 'subjugating' and 'subjugated' (Sebastian, 2016, p. 51). For this polar difference between males and females, the relation between them is most of the time exploiter and exploited. Males do not think the females are equal partners and this unequal relationship advances toxicity, chauvinism, sexism, and so on. A Thousand Splendid Suns is a story of sexism and 
the consequences of sexism. It groups the characters into two categories: villains and heroes where oppressors are villains and oppressed ones are heroes. The heroes suffer and thereby win sympathy and admiration from the reader. Here Mariam and Laila are heroes for their woes and resistance, and Jalil and Rasheed are villains for their cruelty and defeat. The cause of war between these two groups is undeniably sexism that makes their world so toxic that no songs of compromise, forgiveness, and love can be tuned. The male characters' false consciousness of masculinity confines them so much that they do not find any way to escape. As a result, their lives also are devastated along with the devastation of women's lives. They embrace their tragic end silently.

Jalil is a chauvinist character who does not value the urge of his daughter for losing his face in society. When he realizes his fault, the gap between the father and daughter is so huge that he cannot even talk to Mariam let alone asking forgiveness:

He'd stood there for hours, waiting for her, now and then calling her name, just as she had once called his name outside his house. Mariam had parted the curtain once, just a bit, and caught a glimpse of him. Only a glimpse, but long enough to see that his hair had turned fluffy white, ... he was thinner, much thinner. (Hosseini, 2007, p. 301)

If Mariam had forgiven him, their life might have been changed to something better. However, the denial from Mariam and his sense of guilt breaks his heart into pieces. He dies on his way back silently. His tragedy lies here, "He was dying then. He had driven all the way from Herat to say good-bye" (Hosseini, 2007, p. 303). Mariam also shows excessive pride when Jalil comes to her door. Therefore, she regrets after his death, "What would have been the harm to let him in, sit with him, let him say what he'd come to say?" (Hosseini, 2007, p. 302). Sexism hinders their way to healthy bondage.

Sexism also damages the healthy relationships in Rasheed's house. To exert his masculine power, he shows aggression on Mariam and Laila after Mariam's miscarriages and Laila's giving birth to Aziza and their plan to escape the house. The air in the domestic space is so deadly that the wives always live in fear of the husband. The consequence of their pains is also awful, Rasheed's "brutality can be compared to that of the Taliban as both show their inhuman act to uphold their so-called masculine power. The more Rasheed mentally and physically tortures them, the more their mother-daughter bond grows stronger" (Yeasmin \& Islam, 2021, p. 24). Mariam and Laila resist him, and Mariam takes a crucial decision to murder him to rescue her loving ones. Rasheed has been an affectionate father to Zalmai but dies as a villain. His demise echoes the fate of Okonkwo in Achebe's Things Fall Apart whose fear of being termed as weak causes his downfall. His fear leads him to kill Ikemefuna and to take many irrational decisions that make many people of his clan go against him. Like Okonkwo, Rasheed also is afraid of losing control of his wives and decides to kill them which ironically causes his tragic ruin.

Showing the tragic consequences of toxic masculinity, Hosseini also urges for healthy masculinity for reducing sexism and the violence born out of it. In the novel, Mullah Faizullah is a representative of caring masculinity. He teaches Mariam reading, playing, and reciting the Koran. Sometimes, Mariam shares the things that she does not share even with her mother, Nana. Hakim is a caring husband and father. Ignoring the expectations of society, Hakim values his wife's opinion, cares for his daughter, ensures education for her, does everything for the comfort of Fariba and Laila. He is progressive and educated. Tariq is another symbol of healthy masculinity. Tariq's sense of healthy masculinity makes Laila feel "anchored", "sheltered" (Hosseini, 2007, p. 374) a feeling that she never felt with Rasheed. Laila's life in Murree is contented and tranquil with Tariq. When Laila wishes to back to Kabul, Tariq values her wish and comes back to Kabul. He allows Laila the freedom to visit Herat, the birthplace of Mariam, alone. This freedom enjoyed by Laila does not mean that the 
common females of Afghanistan want to subvert order. The females do not want that; they want the freedom of expression, freedom of movement, freedom to fight for their rights. They also crave such kind of protection where they are respected as human beings, not victims of gender apartheid. Laila enjoys the sanctuary of Babi and Tariq as she gets her own space there.

The novel calls for the reduction of sexism showing the victimization and poignant fate of toxic masculine characters whose sexist activities exclude them from the empire of compassion. It ends with an encouraging tone demonstrating the merits of healthy masculinity. Laila and Tariq with Aziza and Zalmai are living in Kabul. Laila is teaching the kids in the orphanage. She is conceiving a baby girl in her womb. She has decided on the baby's name, that is Mariam. The fate of the girl will not be like the woman, Mariam, who had endured brutality all her life and finally killed the oppressor. The baby girl will live in a good world where the males will discard their false concept of masculinity accepting the truth that "A woman is a being. She is not an appendage of man. A woman is not the other. She is not an addition to man" (qtd. in Akhtar et al., 2017, p. 116).

\section{Conclusion}

The article studies toxic masculinity as a potential discourse addressing its evil consequences on the characters' lives. The study argues that toxic masculinity snares men in vague supremacy that prohibits men to highlight their humanitarian agencies, however, contributes to the continuation of gender binaries. Toxic masculinity makes men to forget their true self which is as sensitive as women. To retain their authority over women, men pretend to be strong but silently suffer a lot by hiding their actual feelings. This chauvinistic attitude soaks men's psyche and makes them aggressive and violent for which they face tragic ends. In $A$ Thousand Splendid Suns, Khaled Hosseini portrays toxic men and their agonies. Jalil and Rasheed are the poor victims of patriarchy and male chauvinism. They suffer inwardly but are not privileged like women to express their despairs. However, this issue is unaddressed in society, in culture, even in academia. This study calls for reducing sexism screening the devastative effects of toxic masculinity. It offers a message to the world that a healthy relationship is crucial for a nonviolent world; otherwise, both genders will be the victims of sexism. It recommends a radical reform in patriarchal law and form benevolent atmosphere so that people can live peacefully.

\section{References}

Akhtar, S., Rauf, M., Ikram, S., \& Raees, G. (2017). A legitimate end to illegitimate beginning: A critical analysis of Mariam's character in A Thousand Splendid Suns. English Language and Literature Studies, 7(1), 113-119. doi:10.5539/ells.v7n1p113

Azzi, M., S., Belkhiri, M., Y. (2019). Patriarchy and gender stereotyping in Khaled Hosseini's A Thousand Splendid Suns (M.A. Thesis, University of M'sila). Retrieved from http://dspace.univ-msila.dz:8080/xmlui/handle/123456789/14471

Chaplin, T., and Aldao, A. (2013). Gender differences in emotion expression in children: A meta-analytic review. Psychol Bull, 139(4), 735-765. Doi: 10.1037/a003073

Ghosh, H. A. (2003). A history of women in Afghanistan: Lessons learnt for the future or yesterdays and tomorrow: Women in Afghanistan. Journal of International Women's Studies, 4(3), 1-14. http://vc.bridgew.edu/jiws/vol4/iss3/1

Hosseini, K. (2017). A Thousand Splendid Suns. Bloomsbury Publishing Plc.

Ingram, K., M., Davis, J., P., Espelage, D., L., Hatchel, T., Merrin, G., J., Valido, A.,

Iynisha, G., \& Shanti, D., K. (2018). Masculinity: A gamut in A Thousand Splendid Suns by Khaled Hosseini." Language in India, 18(2), 78-84. 
Kazemiyan, A. (2012). A Thousand Splendid Suns: Rhetorical vision of Afghan women (M. A. thesis, University of Ottawa, Canada). Retrieved from https://ruor.uottawa.ca/bitstream/10393/22680/1/Kazemiyan_Azam_2012_Thesis.pdf

Riany, S. A. A. (2017). The impact of oppression toward women seen through two women characters in Khaled Hosseini's A Thousand Splendid Suns (Undergraduate thesis, Sanata Dharma University, Yogyakarta). Retrieved from https://repository.usd.ac.id/9510/2/124214130_full.pdf

Sebastian, A. (2016). Feminine power as represented in Khaled Hosseini's A Thousand Splendid Suns. Impact: International Journal of Research in Humanities, Arts and Literature, 4(11), 51-58.

Torgal, C. (2019). Longitudinal associations between features of toxic masculinity and bystander willingness to intervene in bullying among middle school boys. Journal of School Psychology, 77, 139-151. Doi: 10.1016/j. jsp.2019.10.007

Thompson, E. H., \& Pleck, J. H. (1986). The structure of male role norms. American Behavioral Scientist, 29(5), 531-543. Doi: 10.1177/000276486029005003

Waling, A. (2019). Problematising 'toxic' and 'healthy' masculinity for addressing gender inequalities." Australian Feminist Studies, 1-15.

Yeasmin, F. (2000). Khaled Hosseini's A Thousand Splendid Suns: A saga of Afghanistan. Research Journal of English Language and Literature (RJELAL), 8(3), 381-390.

Yeasmin, F., \& Islam. S. (2021). The concept of parenthood in Khaled Hosseini's The Kite Runner and A Thousand Splendid Suns. Journal of Critical Studies in Language and Literature, 2(6), 19-27. https://doi.org/10.46809/jcsll.v2i6.92 